\title{
Kuivaamaton perunaproteiini lihasikojen rehuna
}

\author{
Hilkka Siljander-Rasi1) ja Jarmo Valaja ${ }^{2)}$ \\ MTT Kotieläintuotannon tutkimus, ${ }^{1)}$ Tervamäentie 179, 05840 Hyvinkää, hilkka.siljander-rasi@mtt.fi \\ 2)31600 Jokioinen, jarmo.valaja@mtt.fi
}

\section{Tiivistelmä}

Perunatärkkelysteollisuuden sivutuotteena syntyvästä solunesteestä saadaan perunaproteiinia saostamalla valkuaisfraktio lämmön ja $\mathrm{pH}: n$ säätelyn avulla. Proteiinin valmistus olisi kausiluonteista tehtaan toimiessa syksyisin. Toistaiseksi soluneste levitetään pelloille. Tutkimuksessa selvitettiin kuivaamattoman perunaproteiinin ravintoaineiden kokonais- ja ohutsuolisulavuus sioilla ja käyttömäärä soijarouheen korvaajana lihasikojen ruokinnassa.

Sulavuuskokeessa oli neljä ohutsuolikanyloitua $60 \mathrm{~kg}$ painoista leikkosikaa. Koemallina oli $4 * 2$ change-over. Tutkittu valkuaisrehu, kotimainen kuivaamaton perunaproteiini (Finnamyl Oy) tai kuivattu perunaproteiinivalmiste (Avebe Feed, Hollanti) oli sikojen ainoa valkuaisen ja aminohappojen lähde. Ruokintakokeessa oli 112 lihasikaa pariruokinnalla painovälillä 27-110 kg. Imisät ja leikot kasvatettiin erikseen. Ohrapohjaisissa rehuissa korvattiin 0, 25, 50 tai $75 \%$ soijarouheen valkuaisesta kuivaamattoman perunaproteiinin valkuaisella. Sioilla oli kaksivaiheruokinta (1,5-3,2 ry/d).

Kuivaamattomassa perunaproteiinissa oli kuiva-ainetta noin $200 \mathrm{~g} / \mathrm{kg}$, raakavalkuaista $650 \mathrm{~g} / \mathrm{kg}$ ka ja lysiiniä 8,8 g/100 g raakavalkuaista. Se oli tahmaantuvaa massaa, jonka käsittely oli vaikeaa. Ravintoaineiden kokonaissulavuus oli huonompi kuin kuivatun perunaproteiinin. Erityisesti kuivaamattoman perunaproteiinin raakavalkuainen suli huonommin kuin kuivatun $(83,3 \%$ vs. 95,0 \%, $\mathrm{P}<0,10)$. Tämän vuoksi kuivaamattoman perunaproteiinin rehuyksikköarvo oli pienempi kuin kuivatun (0,87 vs. $1,01 \mathrm{ry} / \mathrm{kg}$ ). Kuivaamattoman perunaproteiinin lysiinin, metioniinin ja treoniinin ohutsuolisulavuus oli $72,1 \%, 74,8 \%$ ja $68,5 \%$ ja kuivatun perunaproteiinin vastaavasti $89,5 \%, 93,5 \%$ ja $89,3 \%(\mathrm{P}<0,05)$.

Kasvatuskokeessa soijarouheen valkuaisen korvaaminen perunaproteiinin valkuaisella ei vaikuttanut sikojen päiväkasvuun tai kasvatusaikaan. Siat kasvoivat 986 g, 1009 g, 1007 g ja 1003 g/d korvattaessa soijan valkuaisesta $0,25,50$ ja $75 \%$ perunaproteiinilla. Rehuhyötysuhdetta perunaproteiinin käyttö paransi suoraviivaisesti $(2,59,2,49,2,50 \mathrm{ja} 2,45 \mathrm{ry} / \mathrm{kg}, \mathrm{P}<0,001)$. Perunaproteiini ei vaikuttanut sikojen ruhon lihaprosenttiin $(59,0,59,5,59,5$ ja $58,9 \%)$.

Kuivaamattoman perunaproteiinin aminohappojen sulavuus vastasi ohran aminohappojen sulavuutta, mutta siinä oli sulavaa lysiiniä noin $41 \mathrm{~g} / \mathrm{kg}$ ka, eli enemmän kuin soijarouheessa. Syynä kuivaamattoman perunaproteiinin kaupallista valmistetta huonompaan aminohappojen sulavuuteen voivat olla haitta-aineet tai prosessointiolosuhteet.

Lihasikojen ruokinnassa kuivaamattomalla perunaproteiinilla voidaan korvata $75 \%$ soijarouheen valkuaisesta, jolloin sen käyttömäärä rehun kuiva-aineesta on noin $11 \%$ alkukasvatuksessa ja 7 \% loppukasvatuksessa. Perunaproteiinin kuiva-ainepitoisuutta tulisi pienentää, jotta rehu olisi juoksevaa. Perunaproteiinilla olisi arvokkaan valkuaiskoostumuksensa takia käyttöä porsasrehuissa. Tätä tarkoitusta varten rehu tulisi kuivata.

\section{Asiasanat}

Lihasika, peruna, valkuainen, aminohapot, sulavuus 


\section{Johdanto}

Perunatärkkelystä valmistetaan elintarvikkeeksi ja paperiteollisuuden tarpeisiin. Tärkkelyksen valmistusprosessin sivutuotteena syntyy solunestettä ja kuitupitoista perunapulppaa. Suomessa tärkkelyksen tuotanto on kausiluonteista ja kestää noin kolme kuukautta elokuusta alkaen. Soluneste levitetään tehtaan lähitilojen pelloille ja pulppa käytetään märehtijöiden ruokintaan. Solunesteestä on mahdollista seostaa proteiinifraktio, mutta Suomessa ei toistaiseksi ole tähän valmista teollista prosessia.

Soluneste sisältää valtaosan perunan liukoisesta valkuaisesta. Perunassa on valkuaista $60-120$ $\mathrm{g} / \mathrm{kg}$ ka. Kokonaistypestä $30-50 \%$ on liukoista proteiinia, $10 \%$ liukenematonta proteiinia pääosin kuoressa ja loppu on liukoista ei-proteiinityppeä. Tästä noin puolet on amideja ja loput aminotyppeä. Aminohappokoostumus sopii hyvin sikojen ruokintaan. Perunan valkuaisessa on lähes yhtä paljon lysiiniä (noin $5 \mathrm{~g} / 100 \mathrm{~g}$ raakavalkuaista) kuin soijarouheessa. Rajoittavat aminohapot sikojen ruokinnassa ovat metioniini ja isoleusiini. Lajike ja kasvuolot vaikuttavat valkuais- ja aminohappopitoisuuteen. Perunassa on valkuaisen sulavuutta huonontavia kymotrypsiini-inhibiittoreita. Ne ovat proteiineja, jotka tuhoutuvat kuumennettaessa. (Edwards \& Livingstone 1990).

Perunaproteiini valmistetaan saostamalla solunesteestä proteiinifraktio lämmön ja $\mathrm{pH}: n$ säätelyn avulla. Perunaproteiini sisältää valkuaista $760-820 \mathrm{~g} / \mathrm{kg} \mathrm{ka}$, lysiiniä $68-81 \mathrm{~g} / \mathrm{kg} \mathrm{ka}$, metioniinia + kystiiniä 32-34 g/kg ka ja treoniinia 44-51 g/kg ka (Lenis et al 1992, Hackl 1996). Yleensä perunaproteiini kuivataan rehukäyttöön.

Perunassa, erityisesti vihertyneissä osissa, iduissa ja kuorissa on myrkyllisiä glykoalkoloideja, $\alpha$-solaniinia ja $\alpha$-kakoniinia. Niiden maku on karvas ja polttava. Perunan glykoalkaloidit kestävät hyvin kuumennusta. Glykoalkaloidimyrkytys aiheuttaa $\mathrm{mm}$. pahoinvointia, suolistotulehduksen ja erilaisia hermosto-oireita (Friedman 2006). Glykoalkaloidien sietokyky vaihtelee eläinlajeittain ja yksilöittäin, mutta sioille myrkyllistä määrää ei tiedetä. Glykoalkaloidien vähentämiseen perunaproteiinin valmistuksessa on olemassa teknologiaa (Friedman 2006).

Vähän glykoalkaloideja sisältävä kuivattu perunaproteiini soveltuu hyvän sulavuutensa ja aminohappokoostumuksensa vuoksi porsasrehuihin korvaamaan esim. plasmatuotteita tai kalajauhoa (Kerr et al. 1998, Pedersen \& Lindberg 2004). Sitä käytetään porsaiden rehuseoksissa alle $10 \%$.

Suomessa perunaproteiinille olisi käyttömahdollisuuksia myös kuivaamattomana, koska liemiruokinta on yleistä erityisesti lihasikaloissa. Tulevaisuudessa perunan solunesteen levitys pelloille voi myös vaikeutua ympäristösyistä. Kuivaamattoman proteiinin rehuarvosta ja soveltuvuudesta sikojen ruokintaan on kuitenkin hyvin vähän tietoa. Tämän tutkimuksen tarkoituksena oli selvittää kuivaamattoman perunaproteiinin ravintoaineiden kokonais- ja ohutsuolisulavuus sioilla ja käyttömäärä soijarouheen korvaajana lihasikojen ruokinnassa. Tutkimus oli osa Satafood Kehittämisyhdistys Ry:n koordinoimaa kehityshanketta.

\section{Aineisto ja menetelmät}

Tutkimuksissa käytetyt perunaproteiinierät valmistettiin pilotmittakaavassa VTT:ssä 2005 (sulavuuskoe) ja Finnamyl Oy:ssä 2006 (ruokintakoe). Solunesteeseen syötettiin rikkidioksidia pH:n säätämiseksi. Nestettä lämmitettiin johtamalla siihen höyryä. Soluneste pumpattiin dekantteriin, jossa erotettiin proteiinisakka liemestä. Kokeisiin käytetyistä eristä poistettiin vettä, jotta kuiva-ainepitoisuus olisi noin $200 \mathrm{~g} / \mathrm{kg}$. Perunaproteiini varastoitiin pakastettuna ilman säilöntäaineita.

Sulavuuskokeessa oli neljä post valve T-caecum eli PVTC-menetelmällä ohutsuolikanyloitua leikkosikaa. Niiden elopaino kokeen alussa oli noin $60 \mathrm{~kg}$. Siat olivat kokeen ajan 1,2 x 1,4 m metaboliakarsinoissa. Koemallina oli $4 * 2$ change-over. Koekäsittelyitä oli kaksi: kuivaamaton perunaproteiini ja kontrollina kuivattu perunaproteiinivalmiste (Avebe Feed, Hollanti). Tutkittava valkuaisrehu oli sikojen ainoa valkuaisen ja aminohappojen lähde. Rehuissa oli kuivaamatonta perunaproteiinia $233 \mathrm{~g} / \mathrm{kg}$ tai kuivattua $184 \mathrm{~g} / \mathrm{kg}$ kuiva-ainetta. Rehut sisälsivät lisäksi tärkkelystä, selluloosaa, sokeria, ruokintakalkkia, monokalsiumfosfaattia, ruokasuolaa ja hiven-vitamiiniseosta. Kuivaamatonta perunaproteiinia sisältäneen rehun analysoitu raakavalkuaispitoisuus oli $167 \mathrm{~g} / \mathrm{kg}$ ka ja kuivattua proteiinia sisältäneen $166 \mathrm{~g} / \mathrm{kg} \mathrm{ka}$. Rehujen lysiinipitoisuudet olivat vastaavasti $14,3 \mathrm{ja} 15,1 \mathrm{~g} / \mathrm{kg} \mathrm{ka}$. Nestemäinen ja kuiva perunaproteiini ja muista aineosista tehdyt esiseokset punnittiin erikseen ja sekoitettiin ennen ruokintaa. Merkkiaine (kromioksidi $0,6 \mathrm{~g} / \mathrm{kg} \mathrm{ka}$ ) punnittiin erikseen ja sekoitettiin rehuun. Siat ruokittiin kahdesti päivässä, klo $6.00 \mathrm{ja}$ klo 18.00 .

Koejaksoja oli kaksi, joissa valmistuskauden pituus oli $7 \mathrm{~d}$, sonnan kokonaiskeruukauden $4 \mathrm{~d}$ ja ohutsuolinesteen keruukauden 2 d. Ohutsuolinesteen keruupäivien välissä oli yksi päivä. Suolinestettä 
kerättiin ensimmäisenä päivänä klo 6-8, 10-12 ja 14-16 ja toisena päivänä klo 8-10, 12-14 ja 16-18. Sonta kerättiin sian peräaukon ympärille kiinnitettyyn muovipussiin. Jakson päätyttyä kunkin sian sontanäytteet sulatettiin ja yhdistettiin eläinkohtaisesti. Ruokasulanäytteet yhdistettiin ja sekoitettiin vastaavasti jäisinä.

Ruokintakokeessa oli 112 lihasikaa (56 imisää ja 56 leikkoa) pariruokinnalla. Valtaosa sioista oli maatiaisrotuisia tai maatiais- ja yorkshirerodun risteytyksiä. Sikojen elopaino kokeen alussa oli noin $26 \mathrm{~kg}$ ja teurastettaessa $110 \mathrm{~kg}$. Imisät ja leikot kasvatettiin erikseen. Koeryhmiä oli neljä, ja kussakin ryhmässä oli 7 imisä- ja 7 leikkokarsinaa (yhteensä 28 sikaa).

Sikojen ruokinnassa (koeryhmät 1-4) korvattiin soijarouheen valkuaisesta $0,25,50$ tai $75 \%$ kuivaamattoman perunaproteiinin valkuaisella. Sioilla oli kaksivaiheruokinta. Alkukasvatusrehuissa oli soijarouhetta $17,91,13,40,9,00$ tai $4,50 \%$ ja perunaproteiinia $0,3,60,7,20$ tai $10,80 \%$ kuivaaineesta. Loppukasvatusrehuissa oli soijarouhetta $11,46,8,60,5,70$ tai $2,90 \%$ ja perunaproteiinia 0 , 2,30, 4,60 tai 6,90\% kuiva-aineesta. Rehujen muut aineosat olivat ohra, ruokintakalkki, monokalsiumfosfaatti, vitamiini-hivenaine-ruokasuolaseos, L-lysiini-HCl, L-treoniini ja alkukasvatusrehuissa DL-metioniini. Perunaproteiinin rehuarvo ja sulavien aminohappojen määrä laskettiin käyttäen sulavuuskokeessa määritettyjä kertoimia ja muiden raaka-aineiden sulavuus otettiin rehutaulukoista (MTT 2004). Alkukasvatusrehuissa oli sulavaa raakavalkuaista (SRV) $151 \mathrm{~g} / \mathrm{ry}$, sulavaa lysiiniä $9,5 \mathrm{~g} / \mathrm{ry}$ ja sulavaa treoniinia 5,7 g/ry. Loppukasvatusrehuissa oli $125 \mathrm{~g} \mathrm{SRV/ry}$, sulavaa lysiiniä 7,0 g/ry ja sulavaa treoniinia 4,2 g/ry. Ryhmän 1 ohra-soijaseos ja muiden ryhmien kuivat esiseokset tehtiin MTT:n Jokioisten rehunsekoittamossa ja rakeistettiin (rakeen läpimitta $4 \mathrm{~mm}$, höyryrakeistus).

Alkukasvatusrehuja annettiin 32 ensimmäistä päivää. Siat ruokittiin kahdesti päivässä. Ensimmäisellä viikolla rehuannos oli $1,5 \mathrm{ry} / \mathrm{sika} / \mathrm{d}$. Annos nostettiin 9 viikon aikana maksimimäärään $(3,2$ ry/sika/d). Perunaproteiini oli varastoitu 200 1:n tynnyreihin, ja sikojen kuiva-aineen saantia korjattiin etukäteen tehtyjen tynnyrikohtaisten kuiva-ainemääritysten perusteella. Kuivien seosten ja perunaproteiinin päiväannokset punnittiin ämpäreihin ja jaettiin silmämääräisesti puoliksi kahdelle ruokintakerralle. Rehuannosta pudotettiin tilapäisesti, jos sika ei syönyt annostaan. Kaikki rehut kostutettiin vedellä, veden ja kuivan rehun suhde oli noin 2:1.

Ruhon lihaprosentti määritettiin Hennessy GP-mittauksella. Sulavuuskokeen aineiston tilastollinen analyysi tehtiin SAS-ohjelmiston GLM-ohjelmalla. Tilastollisessa mallissa olivat koekäsittelyn, eläimen ja jakson vaikutukset. Kasvatuskokeen tilastollinen analysointi tehtiin SAS-ohjelmiston MIXED-ohjelmalla. Tuotantotulosten havaintoyksikkönä oli karsinan sikojen tulosten keskiarvo, teurastulosten havaintoyksikkönä oli yksittäisen sian ruho. Tilastollisessa mallissa oli koekäsittelyn ja sukupuolen vaikutus sekä näiden yhdysvaikutus. Perunaproteiinin vaikutusta testattiin ortogonaalisin polynomein (suoraviivainen sekä 2. ja 3. asteen käyräviivaiset vaikutukset). Perunaproteiiniryhmiä verrattiin myös ohra-soijaruokintaan Dunnettin testillä.

\section{Tulokset ja tulosten tarkastelu}

Perunaproteiini oli sulatuksen jälkeen sementin harmaata, tahmaantuvaa ja sormin muovailtavaa massaa, joka kuitenkin sekoittui nopeasti veteen. Haju oli mieto. Säilyvyys oli melko hyvä, kun tynnyrit pidettiin suljettuina viileässä. Joissain tynnyreissä rehu alkoi homehtua pinnalta. Tutkittujen perunaproteiinien koostumus näkyy taulukossa 1 . Kuivaamattoman perunaproteiinin valkuaispitoisuus oli pienempi ja siinä oli vähemmän lysiiniä, metioniinia ja kystiiniä kuin kuivatussa perunaproteiinissa.

Ruokintakokeen perunaproteiinista analysoitiin myös kivennäiset. Runsaimmin oli kaliumia $(21,0 \mathrm{~g} / \mathrm{kg} \mathrm{ka})$ ja rikkiä $(11,6 \mathrm{~g} / \mathrm{kg} \mathrm{ka})$. Rikki on suurimmaksi osaksi peräisin perunatärkkelysprosessista. Fosforin ja kalsiumin pitoisuudet olivat samaa luokkaa kuin ohrassa $(3,5$ ja $0,97 \mathrm{~g} / \mathrm{kg} \mathrm{ka})$. Hivenaineista runsaimmin oli rautaa ja kuparia. Perunaproteiini oli lievästi hapanta ( $\mathrm{pH} 5,2)$. Rehussa oli hyvin vähän maitohappoa. Muita orgaanisia happoja ei analysoitu.

Sulavuuskokeessa kuivatun perunaproteiiniseoksen maittavuus oli huonompi kuin kuivaamattoman perunaproteiinin ja kokeen aikana jäi rehutähteitä. Tästä syystä yhdeltä sialta ei saatu tuloksia kokeen ensimmäisellä jaksolla. Tuoretta perunaproteiinia saaneet siat söivät keruukaudella enemmän (2,20 vs. $1,85 \mathrm{~kg} \mathrm{ka} / \mathrm{pv})$ ja kasvoivat nopeammin kuin kuivattua perunaproteiinia syöneet siat (1286 $\mathrm{g} / \mathrm{pv}$ ja $500 \mathrm{~g} / \mathrm{pv}$ ). Erot eivät olleet tilastollisesti merkitseviä, koska havaintojen määrä oli pieni ja hajonta suuri. 
Taulukko 1. Perunaproteiinierien kemiallinen koostumus (g/kg ka).

\begin{tabular}{|c|c|c|c|}
\hline \multirow[t]{2}{*}{ Perunaproteiini } & \multicolumn{2}{|c|}{ Kuivaamaton } & \multirow{2}{*}{$\begin{array}{c}\text { Kuivattu } \\
\text { Sulavuuskoe }\end{array}$} \\
\hline & Sulavuuskoe & Ruokintakoe & \\
\hline Kuiva-aine, g/kg & 116,9 & 227,3 & 909,5 \\
\hline Tuhka & 92,1 & 48,7 & 6,4 \\
\hline Raakavalkuainen & 642,4 & 681,4 & 865,7 \\
\hline Raakarasva & 45,6 & 20,6 & 33,5 \\
\hline Raakakuitu & 7,2 & 53,9 & 14,8 \\
\hline NDF & 27,4 & & 30,3 \\
\hline \multicolumn{4}{|c|}{ Aminohapot, välttämättömät } \\
\hline Lysiini & 56,3 & 65,0 & 80,7 \\
\hline Metioniini & 14,3 & 20,9 & 21,2 \\
\hline Treoniini & 42,4 & 45,7 & 60,6 \\
\hline Arginiini & 36,4 & 33,5 & 48,2 \\
\hline Histidiini & 16,9 & 17,1 & 22,9 \\
\hline Isoleusiini & 37,6 & 45,7 & 52,1 \\
\hline Leusiini & 77,8 & 71,7 & 113,1 \\
\hline Fenyylialaniini & 46,8 & 42,6 & 65,7 \\
\hline Valiini & 43,4 & 58,4 & 57,0 \\
\hline \multicolumn{4}{|c|}{ Aminohapot, ei-välttämättömät } \\
\hline Kystiini & 12,6 & 12,4 & 12,2 \\
\hline Alaniini & 36,8 & 29,1 & 50,4 \\
\hline Aspargiinihappo & 107,1 & 98,5 & 125,8 \\
\hline Glutamiinihappo & 88,6 & 68,5 & 116,1 \\
\hline Glysiini & 37,7 & 33,6 & 49,4 \\
\hline Proliini & 37,8 & 33,2 & 51,5 \\
\hline Seriini & 39,8 & 35,2 & 56,8 \\
\hline Tyrosiini & 39,7 & 35,8 & 58,0 \\
\hline
\end{tabular}

Kuivatun perunaproteiinin ravintoaineiden kokonaissulavuus oli hiukan parempi kuin kuivaamattoman (Taulukko 2). Erityisesti kuivatun perunaproteiinin raakavalkuainen suli paremmin kuin kuivaamattoman (kokonaiskeruu 83,3 \% vs. 95,0 \%, $\mathrm{P}<0,10$; merkkiaine 79,7 \% vs. 93,8 \%, $\mathrm{P}<0,05$ ). Kuivatun perunaproteiinin raakavalkuaisen ja aminohappojen ohutsuolisulavuus oli selvästi parempi kuin kuivaamattoman perunaproteiinin (Taulukko 2). Kuivatun perunaproteiinin lysiinin, metioniinin ja treoniinin ohutsuolisulavuus oli $89,5 \%, 93,5 \%$ ja $89,3 \%$, ja kuivaamattoman perunaproteiinin vastaavien aminohappojen ohutsuolisulavuus oli 72,1\%, 74,8 \% ja 68,5\%. Ero oli kaikkien aminohappojen osalta tilastollisesti merkitsevä $(\mathrm{P}<0,05)$. Kuivatun perunaproteiinin aminohappojen ohutsuolisulavuus vastasi kohtuullisen hyvin valmistajan ilmoittamia arvoja ja aikaisempia tutkimustuloksia (Lenis et al. 1992). Kuivaamattoman perunaproteiinin aminohappojen sulavuus vastasi ohran aminohappojen sulavuutta.

Määritettyihin sulavuuskertoimiin perustuva kuivatun perunaproteiinin rehuyksikköarvo oli suurempi kuin kuivaamattoman perunaproteiinin (1,01 vs. $0,87 \mathrm{ry} / \mathrm{kg} \mathrm{ka})$. Syynä eroon oli lähinnä kuivan perunaproteiinin parempi raakavalkuaisen sulavuus. Kuivattu perunaproteiini sisälsi myös runsaammin sulavaa raakavalkuaista kuin kuivaamaton ( 818 vs. $612 \mathrm{~g} /$ ry).

Kasvatuskokeessa kaikkien koeryhmien siat söivät suunnitellut annoksensa melko hyvin, tilapäisiä rehun vähennyksiä oli vain muutamia. Sekä ryhmistä 1 että 2 poistettiin yksi sika jalkaongelmien takia ja ryhmästä 2 kuoli yksi sika äkillisesti. Ryhmän 1 yksi sika lääkittiin jalkavaivan takia. Muiden sikojen terveys oli hyvä.

Soijarouheen korvaaminen perunaproteiinilla ei vaikuttanut merkitsevästi sikojen päiväkasvuun tai kasvatusaikaan ( $>0,10$, Taulukko 3), vaikka perunaproteiiniryhmien sikojen päiväkasvu olikin 1,7-2,3 \% parempi kuin ohra-soijaryhmän sikojen. Perunaproteiiniruokinnan vaikutus oli samanlainen molemmilla sukupuolilla.

Perunaproteiinin lisäys ei vaikuttanut sikojen kuiva-aineen tai energian päiväsyöntiin, mutta vähensi kulutettujen rehuyksiköiden kokonaismäärää suoraviivaisesti ( $\mathrm{P}=0,09$, Taulukko 3). Rehunkulutus ei kuitenkaan poikennut merkitsevästi soijaryhmän sikojen rehunkulutuksesta. Energian rehuhyötysuhdetta perunaproteiinin lisäys paransi suoraviivaisesti loppukasvatuksessa $(\mathrm{P}<0,001)$. 
Taulukko 2. Kuivaamattoman ja kuivatun perunaproteiinin ravintoaineiden kokonais- ja ohutsuolisuolisulavuus.

\begin{tabular}{|c|c|c|c|c|}
\hline Perunaproteiini & Kuivaamaton & Kuivattu & SEM & Merkitsevyys \\
\hline \multicolumn{5}{|l|}{ Kokonaissulavuus $^{1}$} \\
\hline Kuiva-aine & 91,7 & 95,8 & 0,56 & \\
\hline Orgaaninen aine & 92,2 & 95,5 & 0,06 & $*$ \\
\hline Tuhka & 79,5 & 78,9 & 2,81 & \\
\hline Raakavalkuainen & 83,3 & 95,0 & 0,83 & o \\
\hline Raakarasva & 50,8 & 59,0 & 1,98 & \\
\hline NDF & 54,8 & 50,4 & 2,53 & \\
\hline \multicolumn{5}{|l|}{ Ohutsuolisulavuus $^{2}$} \\
\hline Kuiva-aine & 83,2 & 89,1 & 0,19 & $*$ \\
\hline Orgaaninen aine & 84,5 & 90,3 & 0,03 & $* *$ \\
\hline Tuhka & 62,2 & 60,2 & 2,53 & \\
\hline Raakavalkuainen & 66,2 & 88,0 & 1,44 & o \\
\hline \multicolumn{5}{|c|}{ Aminohapot, välttämättömät } \\
\hline Lysiini & 72,1 & 89,5 & 0,47 & $*$ \\
\hline Metioniini & 74,8 & 93,5 & 0,12 & $* *$ \\
\hline Treoniini & 68,3 & 89,3 & 0,88 & $*$ \\
\hline Arginiini & 80,5 & 93,2 & 0,65 & $*$ \\
\hline Histidiini & 70,6 & 89,9 & 1,00 & $*$ \\
\hline Isoleusiini & 71,6 & 91,5 & 0,63 & $*$ \\
\hline Leusiini & 75,1 & 93,3 & 1,35 & $\mathrm{o}$ \\
\hline Fenyylialaniini & 74,8 & 92,6 & 1,13 & $*$ \\
\hline Valiini & 71,4 & 90,4 & 1,31 & o \\
\hline \multicolumn{5}{|c|}{ Aminohapot, ei-välttämättömät } \\
\hline Kystiini & 54,7 & 78,6 & 1,68 & $\mathrm{o}$ \\
\hline Alaniini & 73,3 & 90,1 & 1,03 & $*$ \\
\hline Aspargiinihappo & 70,0 & 89,0 & 1,12 & $*$ \\
\hline Glutamiinihappo & 73,2 & 91,0 & 0,95 & $*$ \\
\hline Glysiini & 62,8 & 86,9 & 1,86 & o \\
\hline Proliini & 74,5 & 90,4 & 0,50 & $*$ \\
\hline Seriini & 67,7 & 88,6 & 1,56 & o \\
\hline Tyrosiini & 77,8 & 94,9 & 1,03 & $*$ \\
\hline
\end{tabular}

${ }^{1}$ kokonaiskeruu, ${ }^{2}$ kromimerkkiaine, SEM=keskiarvon keskivirhe (3 havainnolle).

Myös koko kasvatuskauden rehuhyötysuhde $(\mathrm{kg} \mathrm{ka} / \mathrm{kg}$, ry/kg) parani suoraviivaisesti perunaproteiinia lisättäessä $(\mathrm{P}<0,001)$. Koko kasvatuskauden rehuhyötysuhde oli kaikissa perunaproteiiniryhmissä merkitsevästi parempi $(3,5-5,7 \%)$ kuin soijaryhmän sioilla $(\mathrm{P}<0,05)$. Tulos voi viitata siihen, että perunaproteiinin todellinen energia-arvo sikojen ruokinnassa oli parempi kuin sulavuuskokeen sulavuuskertoimilla laskettu energia-arvo.

Saksalaisessa tutkimuksessa (Hackl 1996) korvattiin soijarouheen valkuainen perunaproteiinilla lihasikojen (33-108 kg) ruokinnassa. Perunaproteiiniryhmän sikojen kasvu oli noin $6 \%$ ja rehun energian hyötysuhde $11 \%$ parempi kuin soijaryhmän sikojen. Sikojen raakavalkuaisen saanti soijarouheesta ja ohrasta olivat samat, mutta rehujen aminohappoja ei tasattu. Perunaproteiinilla ruokitut siat todennäköisesti saivat enemmän välttämättömiä aminohappoja kuin soijarouheella ruokitut.

Sikojen teuraspainossa $(\mathrm{P}<0,05)$ ja teurastustappioprosentissa $(\mathrm{P}=0,07)$ havaittiin perunaproteiinilisäyksen käyräviivainen vaikutus (Taulukko 3). Teuraspaino oli suurin ja teurastustappio pienin ryhmän 2 sioilla. Ilmiölle ei löydy ruokinnallista selitystä. Teuraspainon kasvaessa sikojen teurastustappio yleensä pienenee. Ruhon lihaprosentin laskentaa varten otetut kylkisilavamitat S1 ja S2 sekä ulkofileen paksuus eivät muuttuneet merkitsevästi lisättäessä perunaproteiinin osuutta ruokinnassa. Ruhon lihaprosentti oli paras, kun 25 tai $50 \%$ soijan valkuaisesta korvattiin perunaproteiinilla, mutta ero soijaryhmään ei ollut merkitsevä. Perunaproteiinin vaikutus teurasominaisuuksiin oli molemmilla sukupuolilla samanlainen.

\section{Johtopäätökset}

Kuivaamattoman perunaproteiinin valkuaisen ja aminohappojen sulavuus on selvästi huonompi kuin kaupallisen kuivatun perunaproteiinin aminohappojen sulavuus. Mahdollisia syitä huonompaan sulavuuteen voivat olla haitta-aineet tai prosessointiolosuhteet. Vaikka kuivaamattoman perunaproteiinin 
aminohappojen sulavuus vastasi ohran aminohappojen sulavuutta, siinä oli enemmän sulavaa lysiiniä (noin $41 \mathrm{~g} / \mathrm{kg} \mathrm{ka}$ ) kuin soijarouheessa.

Tulosten perusteella kuivaamattoman perunaproteiinin valkuaisella voidaan korvata $75 \%$ soijan valkuaisesta lihasikojen ruokinnassa. Perunaproteiinin käytöllä oli edullinen vaikutus sikojen rehuhyötysuhteeseen, joka on lihasikojen kasvatuksen tärkeimpiä taloudellisia mittareita. Kokeessa käytetyssä erässä oli kuiva-ainetta noin $20 \%$, ja rehu oli käytännössä siirrettävä lapioimalla. Tilaolosuhteissa tämä ei ole mahdollista. Tuorekäyttöä varten rehun kuiva-aine olisi optimoitava niin, että rehu pystyttäisiin pumppaamaan varastosäiliöstä liemiruokintalaitteen sekoitussäiliöön.

Perunaproteiini on aminohappokoostumukseltaan arvokas rehu sioille. Sen kuivaaminen mahdollistaisi käytön porsaiden ruokinnassa ja poistaisi rehun saannin kausiluonteisuuden. Arvioitavaksi jää, onko kuivaus kannattavaa. Maatalouden ympäristövaatimusten kiristyminen voi tulevaisuudessa lisätä paineita perunaproteiinin kuivaamiseen.

Taulukko 3. Sikojen kasvu, rehunkäyttö ja teuraslaatu korvattaessa soijarouhetta perunaproteiinilla.

\begin{tabular}{|c|c|c|c|c|c|c|c|}
\hline \multirow{2}{*}{$\begin{array}{l}\text { Soijan valkuaisen korvaus } \\
\text { perunaproteiinin valkuaisella }\end{array}$} & \multirow[b]{2}{*}{$0 \%$} & \multirow[b]{2}{*}{$25 \%$} & \multirow[b]{2}{*}{$50 \%$} & \multirow[b]{2}{*}{$75 \%$} & \multirow[b]{2}{*}{ SEM } & \multicolumn{2}{|c|}{ Merkitsevyys } \\
\hline & & & & & & $\operatorname{lin}$ & quadr \\
\hline \multicolumn{8}{|l|}{ Päiväkasvu, $\mathrm{g}$} \\
\hline Alkukasvatuksessa & 950 & 974 & 954 & 962 & 18,6 & & \\
\hline Loppukasvatuksessa & 1009 & 1034 & 1039 & 1029 & 1808 & & \\
\hline Koko kokeessa & 986 & 1009 & 1007 & 1003 & 12,5 & & \\
\hline Kasvatuksen kesto, d & 83,5 & 82,9 & 83,9 & 83,6 & 1,13 & & \\
\hline \multicolumn{8}{|l|}{ Rehunkulutus, kg ka/sika } \\
\hline Alkukasvatuksessa & 56,3 & 56,0 & 55,1 & 55,1 & 0,85 & & \\
\hline Loppukasvatuksessa & 139,2 & 134,5 & 138,3 & 133,4 & 2,69 & & \\
\hline \multicolumn{8}{|l|}{ Rehuhyötysuhde, $\mathrm{kg} \mathrm{ka} / \mathrm{kg}$} \\
\hline Alkukasvatuksessa & 1,86 & 1,80 & 1,81 & 1,80 & 0,02 & $\mathrm{o}$ & \\
\hline Loppukasvatuksessa & 2,71 & 2,60 & 2,59 & 2,54 & 0,04 & $* *$ & \\
\hline Koko kokeessa & 2,38 & 2,29 & 2,30 & 2,26 & 0,02 & $* * *$ & \\
\hline \multicolumn{8}{|l|}{ Rehuhyötysuhde, ry/kg } \\
\hline Alkukasvatuksessa & 2,01 & 1,96 & 1,96 & 1,95 & 0,03 & & \\
\hline Loppukasvatuksessa & 2,96 & 2,83 & 2,82 & 2,75 & 0,04 & $* * *$ & \\
\hline Koko kokeessa & 2,59 & 2,49 & 2,50 & 2,45 & 0,02 & $* * *$ & \\
\hline \multicolumn{8}{|l|}{ Teurasominaisuudet } \\
\hline Teuraspaino, kg & 78,7 & 80,5 & 79,9 & 79,5 & 0,50 & & $*$ \\
\hline Teurastustappio, $\%$ & 27,9 & 27,1 & 27,4 & 27,7 & 0,31 & & o \\
\hline Kylkisilava S1, mm & 12,3 & 12,2 & 11,5 & 11,9 & 0,43 & & \\
\hline Kylkisilava S2, mm & 12,0 & 11,8 & 11,7 & 12,0 & 0,42 & & \\
\hline Ulkofileen paksuus, mm & 49,6 & 51,8 & 50,8 & 50,0 & 1,01 & & \\
\hline Ruhon lihaprosentti & 59,0 & 59,5 & 59,5 & 58,9 & 0,45 & & \\
\hline
\end{tabular}

\section{Lähteet}

Edwards, S. A. \& Livingstone, R. M. 1990. Potato and potato products. In: Thacker, P.A. \& Kirkwood, R.N. (Eds.): Nontraditional Feed Sources for use in Swine Production, p. 305-314. Butterworth Publishers, Stoneham.

Friedman, M. 2006. Potato glycoalkaloids and metabolites: roles in the plant and in the diet. J. Agric. Food Chem. 54: 8655-8681.

Hackl, W. 1996. Feeding value and use of fresh preserved potato protein for fattening pigs. Landbauforschung Volkenrode, Sonderheft, p. 185.

Kerr, C. A., Goodband, R. D., Smith, J. W.,II, Musser, R. E., Bergstrom, J. R., Nessmith, W. B.,Jr, To-

kach, M. D., \& Nelssen, J. L. 1998. Evaluation of potato proteins on the growth performance of early-weaned pigs. J. Anim. Sci. 76: 3024-3033.

Lenis, N. P., van Diepen, J. T. M., \& Coppoolse, J. 1992. Ileal amino acid digestibility and nutritive value of potato protein and maize. Rapport IVVO-DLO no. 232. Lelystad, Nederland. 20 p.

Pedersen, C. \& Lindberg, J.E. 2004. Comparison of low-glycoalkaloid potato protein and fish meal as protein sources for weaner piglets. Acta Agric. Scand., Sect. A, Anim. Sci. 54: 75-80. 